\title{
MODELING THE EFFICIENCY OF INVESTMENT IN AGRICULTURAL BUSINESS
}
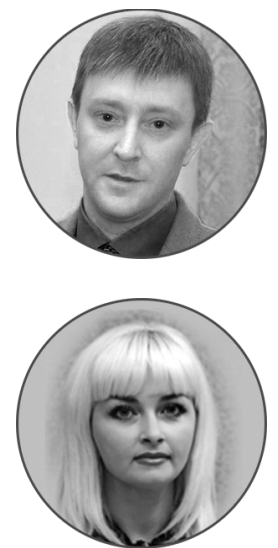

Article history:

Received 30 May 2018

Received in revised form

13 June 2018

Accepted 27 June 2018

Translated 27 August 2018

Available online 28 September 2018

JEL classification: G17, G32, 014

Keywords: agricultural business, investment attractiveness, Economic Value Added, WACC, yield spread

\section{Denis Yu. SAMYGIN}

Penza State University, Penza, Russian Federation

vekont82@mail.ru http://orcid.org/0000-0002-5715-1227

\section{Corresponding author}

\section{Svetlana V. KELEINIKOVA}

Saransk Institute of Cooperation, Branch of Russian University of Cooperation, Saransk, Republic of Mordovia, Russian Federation sveta077@inbox.ru

ORCID: not available

\begin{abstract}
Importance The article discusses how agricultural business can be made more lucrative for investors since there are not appropriate mechanisms to support investment decision-making. Financial measures are not enough to stimulate investing activities of agricultural producers, while the organizational and economic mechanism for creating the favorable investment climate got outdated. Key investment maneuvers are intended to find appropriate ways for outlining a strategy.

Objectives The research systematizes available research tools to evaluate the efficiency of investment, substantiate and devise strategic models for supporting investment decisions in agricultural business.

Methods The research is based on a financial management technique to evaluate the Economic Value Added (EVA) in agricultural business. We supplemented the technique with respective econometric models for measuring the efficiency of investment.

Results The research presents our model showing how the yield spread functionally depends on capital invested in agricultural business. We refer to the Penza oblast to perform all model and analytical computations, which reveal the existing motivation for capital investment and potential for raising the efficiency of agricultural investment.

Conclusions and Relevance There should be tools to substantiate the efficiency of possible investment and visualize the return on investment in the agricultural business so that the agricultural policy could be properly adjusted.
\end{abstract}

๑) Publishing house FINANCE and CREDIT, 2018
Russia has been attempting to depart from the natural resource export paradigm of its national economic development for the recent years. Under

${ }^{\dagger}$ For the source article, please refer to: Самыгин д.Ю., Келейникова С.В. Моделирование эффективности инвестиционных вложений в аграрном бизнесе. Финансы и кредит. 2018. Т. 24. № 7. С. 1609-1620. URL: https://doi.org/10.24891/fc.24.7.1609 the current socio-economic circumstances and restrictions, it is the right time to abandon the oil-forfood rule. To put this idea in practice, rather than simply declare it, the RF Government makes a lot of efforts to raise additional finance and create the favorable climate for the agricultural sector. Following this initiative, first of all, the RF 
Government amended the legislative framework for investment management.

General metrics of capital expenditures and investing activities were updated, with the agroindustrial complex (AIC) being conferred a legal status. Russia has implemented the Priority National Project The Development of Agroindustrial Complex, adopted Federal Law of December 29, 2006 № 264Ф3

On the Development of Agriculture, enacted the Food Security Doctrine, articulated two national programs for agricultural development and regulation of agricultural food markets, materials and food within 2008-2012 and 2013-2020.

Drawing upon the improved legislative grounds, the government is able to expand and reassure its guarantees to agricultural producers. This mobilized budgetary allotments to agriculture, increased credit resources and attracted private investment. In the Penza oblast, the total investment demonstrated 2.7-fold increase in 2015 as compared with 2010 (Fig. 1).

Internal sources of finance for agricultural production grew 2.3 times within 2011-2015, while borrowed sources tripled.

However, this proved to be insufficient. The existing volume of financial resources and applicable tools are only capable of kick-starting the stagnating agricultural economy, ensuring only a 3-percent growth without contributing to extended reproduction of labor tools, objects and resources. A considerable part of agricultural land is still idle. Fiscal limitations necessitate additional financial injections, new sources of funding, which require to apply organizational and economic tools for making agricultural business more lucrative for investors.

If market prices are simply raised, it will cause a food catastrophe. Thus, it cannot be regarded as an alternative option. The banking sector is already involved into the finance of agricultural production through governmental guarantees for subsidizing the interest rate. The other investors demonstrate their reluctance due to high investment risks in the sector. Many of them prefer keeping their funds as bank deposits, government and corporate securities, handling them in financial markets, etc.
To ignite the consumer demand and put investors' focus on the real production sector, central banks outside Russia and national governments introduced the negative interest rate on loans and deposits.

The Russian regions have their own experience in luring investments into the agricultural economy through investment sites for agriculture. They help investors understand the current situation in the food market.

An investment site constitutes a free land plot or a plot with buildings, facilities and utilities, which is provided for investment projects.

We should also mention the program, which was launched in 2014 and designated to support investment projects implemented in Russia. The program was intended to raise the volume of loans extended to the real economy on long-term and beneficial terms. It can be viewed from positive perspectives, considering financial premises it creates for investors. However, there are still organizational and economic issues.

Investment sites in different regions differ considerably in terms of natural and economic aspects, thus having unequal productive capabilities. A would-be investor have no access to such information, being unable to realistically understand competitive profile of different investment sites. Due to this reason, it is not always clear which type of agricultural production will be financially and economically effective, and what food is in high demand inside and outside the regional market.

We analyzed the agrifood policy using the technique of the Organisation for Economic Co-operation and Development (OECD) to outline agricultural profiles of regions. In some cases, the demand for certain types of agricultural products does not always go with their effective production in the regions. The same is true about the supply since highly effective types of products are not always needed in some regions.

As one of the optimal and sensible options, investors may search for reasonable and sound recommendations on projects, which are worth being implemented on certain investment sites, in terms of market efficiency and social relevance, 
provided investors have some governmental guarantees to protect their income.

Such projects should be launched by regional ministries for agriculture. In the case of some investment sites, it is reasonable to prepare alternative projects and justify cash flows, specifying internal financial resources needed, types and volume of the State aid, amount of loan facilities.

Ordinary approaches to investment project feasibility studies should be supplemented with financial management techniques, which would technically streamline investment decision-making processes.

Discounted Cash Flow method (DCF method) may appear to be one of the main techniques to evaluate agricultural business. It is impossible to evaluate the present value of future cash flows without the discount rate. Economically, the Rate of Return on Capital Employed (ROCE), which investors expect, serves as the discount rate concerning investment targets, which are comparable in terms of risk exposure.

The discount rate can also be defined as the value of capital raised from different sources. Cash flows from invested capital are subject to the discount rate that equals the sum of weighted average cost of capital and borrowings, with equity-to-debt ratios of the capital being regarded as percentages (WACC). The metric is used to gauge Economic Value Added (EVA).

EVA represents a method to measure the corporate financial position through real income. What EVA fundamentally means is that corporate capital shall work as effective as possible to ensure ROCE the investor or other shareholder require.

EVA arises if the return on investment turns to be higher for a certain period of time than the rate of return expected by the investor.

The EVA analysis methodology comprises several steps and includes some indicators (Table 1).

The indicators were measured with the software application, Automated System for Comprehensive Financial, Economic and Managerial Analysis of Business.
Several interim iterations are performed to appraise the equity.

1. Risk-free rate of return constitutes a rate on time deposits adjusted for a 12-month inflation.

2. The average return on shares in the stock market is a difference between the market risk premium and risk-free rate of return.

3. The risk of corporate investment in sectoral entities (a beta of listed firms) is assessed through the rating of the borrower's financial position. The assessed beta shall be adjusted for the ratio reflecting the extent to which the return on shares of the agricultural companies fluctuate in comparison with the general stock market return.

4. The risk of investment in small business is assessed through the selling cost of corporate assets and current loan liabilities and payables, when the adjusted liquidity ratio is measured (Table 2).

The nominal risk-free rate turned out to be lower than the inflation. In today's Russia, the nominal riskfree rate based on the government bonds yield cannot be used in the DCF method. However, the negative risk-free rate is unacceptable for WACC computations.

It is very risky to invest in shares of the Russian entities nationwide since the risk premium exceeds the return on shares in the stock market.

Agricultural businesses pertain to the second class of creditworthiness. Therefore, the risk of investment can be assessed as moderate in terms of the market. Beta is considered to equal 0.82 .

According to statistical data, the general return on agricultural companies' shares ranges with the amplitude of 1.

Total beta of goods producers in the Penza oblast is 0.91 in 2015. Privacy premium accounts for 75 percent of the risk-free rate, being equal to 2.53 percent.

Thus, as the analysis shows, the risk of investment in agriculture of the Penza oblast can be assessed as high, being equal to 0.35 . 
At the final step of the analysis, we evaluate the EVA metrics (Table 3).

As per Table 3, WACC of agricultural businesses in the Penza oblast equals the average return on shares in the stock market, i.e. the return can be considered as medium in the sector from perspectives of owners.

For the analyzable period, the cost of debt held by agricultural business considerably exceeds the cost of equity. It means it is a reasonable measure to secure loans for the sector.

WACC is rather low, signifying an increase in the corporate value over time.

Generally, during the analyzable period, the capital employed and its return grow, which is a positive trend.

The following reasoning should be behind the interpretation of EVA metrics. Positive EVA signifies an increase in the market value in comparison with the carrying amount of net assets and motivates owners to continue business investment. Negative EVA decreases the market value of the entity and loss of owners' investment as they do not derive an alternative yield.

Researches based on the Penza oblast data reveal that the market value of agricultural entities has increased for the recent years as compared with the carrying amount of assets, and identified a respective positive trend. In 2013, equity owners did not manage to recover their invested capital in 2013 due to the loss of return. In 2014 and 2015 they were motivated to make additional investments in agricultural business.
The yield spread reflects the portion of EVA, which was gained per ruble of the capital employed. It shows how much the market value of the entity rises if additional contributions are made. In the Penza oblast, each ruble invested in 2014 and 2015 boosted the market value of business by over 2.3 kopecks. This provides grounds to justify a certain amount of financial injections into the real sector of agriculture provided the business has a specific value (Fig. 2).

We analyzed the trend in the ROCE spread by scrutinizing 220 agricultural enterprises of the Penza oblast. As a result of the trend analysis, we captured the power law dependence of the market value on the capital employed. There is a 98-percent probability that each ruble invested will result in the higher market value. The elasticity of the model proves that a 1-percent increase in the capital employed makes the market value go up by 1.04 percent.

Summarizing results of the research, we conclude that a variety of tools and mechanisms are used in today's Russia to manage the investment attractiveness of the agricultural sector. We should emphasize positive changes and trends that have already been observed in this sector. Successful developments primarily proceed from budgetary allotments and the involvement of the banking sector secured with certain governmental guarantees. However, the measures have not yet lured other investors and streamed their private funds into agricultural business.

The framework of investment and financial management is the most appropriate tool to justify the feasibility of possible investments, payback of the capital employed. 


\section{Table 1}

The methodology for Economic Value Added analysis

\begin{tabular}{|c|c|}
\hline Metric & Calculation method \\
\hline The cost of debt $(R d)$ & $\begin{array}{l}\frac{I P}{D} \cdot 100 \\
\text { where IP stands for interests payable (Form } 2 \text { Line 2330); } \\
D \text { is borrowed capital (Form } 1 \text { Line } 1410+\text { Form } 1 \text { Line } 1510 \text { ) }\end{array}$ \\
\hline Debt-to-capital ratio $(D / E)$ & $\begin{array}{l}\frac{D}{A} \\
\text { where } A \text { is balance (Form } 1 \text { Line } 1700)\end{array}$ \\
\hline The cost of equity $(P C K)$ & $\begin{array}{l}R+b t^{*}(R m-R)+x+y+f \\
\text { where } R \text { is the risk-free rate of return; } \\
b t \text { is the risk of investing corporate money through the rating of the } \\
\text { borrower's financial position; } \\
R m \text { is the average return on shares in the stock market; } \\
x \text { is the risk of putting money into the sector; } \\
y \text { is the privacy premium; } \\
f \text { is the country risk premium }\end{array}$ \\
\hline Equity-to-capital ratio $(d C K)$ & $\begin{array}{l}\frac{S C}{A}, \\
\text { where } S C \text { is the share capital (Form } 1 \text { Line 1310) }\end{array}$ \\
\hline Weighted Average Cost of Capital (WACC) & $R d \cdot \quad D / E+P C K \cdot d C K$ \\
\hline Capital Employed (CE) & $\begin{array}{l}A-A P, \\
\text { where } A P \text { are accounts payable }\end{array}$ \\
\hline Return on Capital Employed (ROCE) & $\begin{array}{l}\frac{N P}{C E} \cdot 100 \% \\
\text { where } N P \text { is net profit }\end{array}$ \\
\hline Economic Value Added (EVA) & $(R O C E-W A C C) \cdot \frac{C E}{100 \%}$ \\
\hline Yield spread (Spread) & $\frac{E V A}{C E} \cdot 100$ or $R O C E-W A C C$ \\
\hline
\end{tabular}

Source: Authoring

\section{Table 2}

Analysis of the cost-of-equity factors in relation to agricultural enterprises of the Penza oblast, 2013-2015

\begin{tabular}{llll}
\hline Metrics & $\mathbf{2 0 1 3}$ & $\mathbf{2 0 1 4}$ & $\mathbf{2 0 1 5}$ \\
\hline Risk-free rate of return & 2.17 & 0.09 & 3.37 \\
\hline Market risk premium & 8.05 & 7.4 & 7.4 \\
\hline Average return on equity market & 5.88 & 7.31 & 4.03 \\
\hline Risk of putting corporate capital into agricultural enterprises & 0.91 & 0.81 & 0.91 \\
\hline Adjusted liquidity ratio & 1.253 & 1.432 & 1.265 \\
\hline Risk of putting money into small business & 0.35 & 0.32 & 0.35 \\
\hline Privacy premium & 1.63 & 0.07 & 2.53 \\
\hline
\end{tabular}

Source: Authoring 


\section{Table 3}

Assessment of Economic Value Added metrics in the agricultural business of the Penza oblast

\begin{tabular}{llll}
\hline Metrics & 2013 & 2014 & 2015 \\
\hline The cost of debt & 7.886 & 7.297 & 10.415 \\
\hline Debt-to-capital ratio & 0.547 & 0.521 & 0.524 \\
\hline The cost of equity & 9.35 & 8.83 & 9.78 \\
\hline Equity-to-capital ratio & 0.096 & 0.11 & 0.082 \\
\hline Weighted Average Cost of Capital (WACC) & 5.101 & 4.748 & 6.564 \\
\hline Capital Employed & $44,882,280$ & $50,872,846$ & $61,113,795$ \\
\hline Return on Capital Employed & 1.158 & 7.101 & 8.882 \\
\hline Economic Value Added & $-1,769,637$ & $1,197,172$ & $1,416,337$ \\
\hline Spread on the yield of capital employed, kopecks / RUB & -3.94 & 2.35 & 2.32 \\
\hline
\end{tabular}

Source: Authoring

\section{Figure 1}

The growth rate of investments in agriculture of the Penza oblast in 2011-2015 against 2010, percent

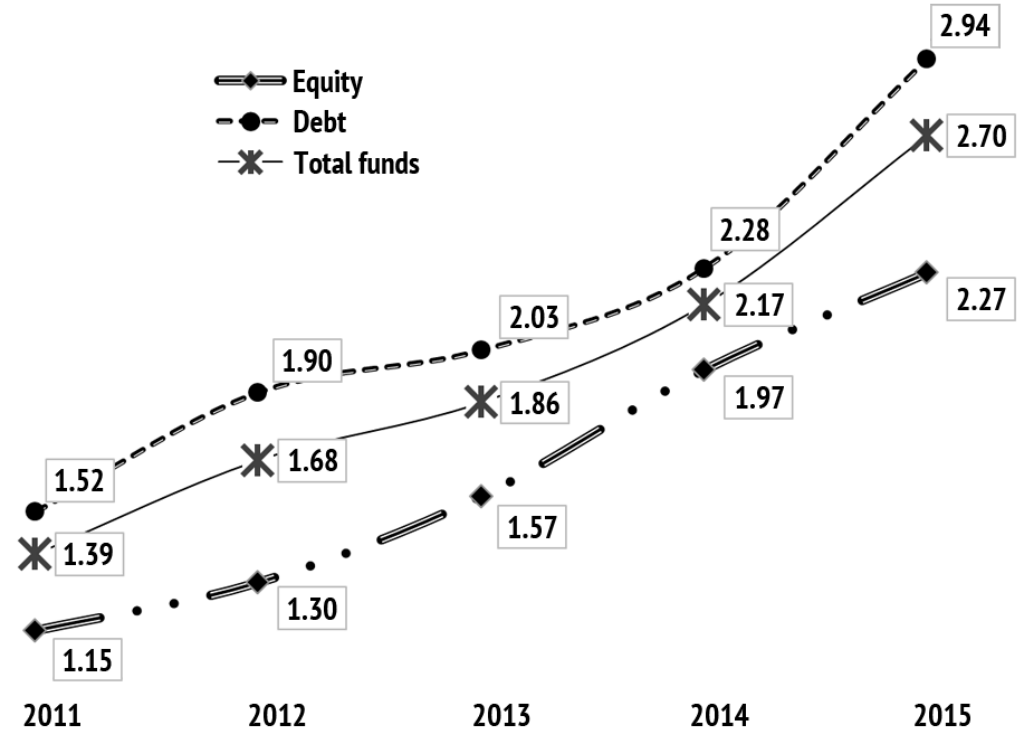

Source: Authoring 


\section{Figure 2}

Models of the correlation between the yield spread and capital invested in the agricultural business

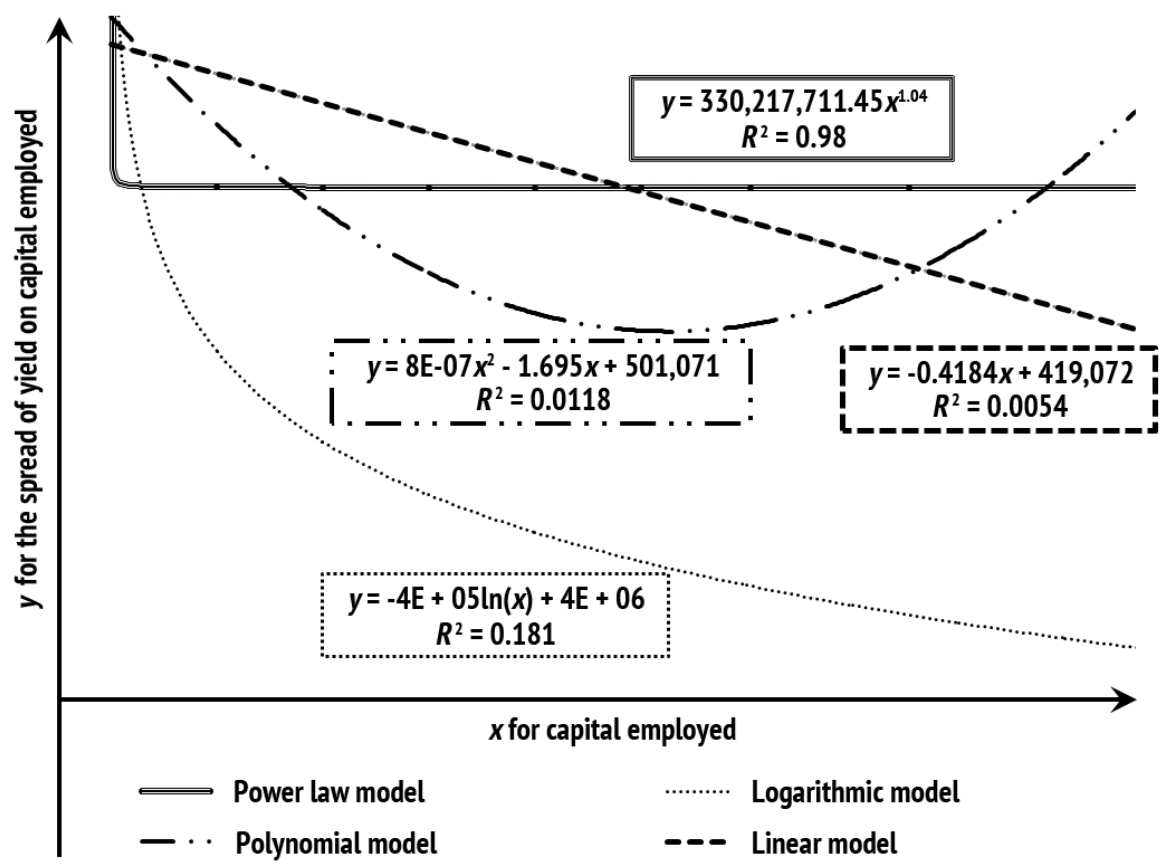

Source:Authoring

\section{Acknowledgments}

The research was supported by the Russian Foundation for Basic Research, project № 16-32-00015-ОГН.

\section{References}

1. Bespakhotnyi G.V. [Planning in Agriculture - Scientific Support]. Ekonomika sel'skokhozyaistvennykh i pererabatyvayushchikh predpriyatii = Economy of Agricultural and Processing Enterprises, 2017, no. 10, pp. 8-12. (In Russ.)

2. Anastassiadis F., Liebe U., Mußhoff O. Financial Flexibility in Agricultural Investment Decisions: A Discrete Choice Experiment. Agricultural Economics Review, 2015, vol. 16, iss. 1, pp. 47-58.

3. Samygin D.Yu., Baryshnikov N.G., Mizyurkina L.A. [Design Model for the Development of Agrarian Economy: Food Aspect]. Economy of Region, 2017, vol. 13, iss. 2, pp. 591-603.

URL: http://economyofregion.ru/Data/Issues/ER2017/June_2017/ERJune2017_591_603.pdf (In Russ.)

4. Cordeiro J.J., Kent D.D. Jr. Do EVA ${ }^{\mathrm{TM}}$ Adopters Outperform Their Industry Peers? Evidence from Security Analyst Earnings Forecasts. American Business Review, 2001, June, pp. 57-63. URL: https://digitalcommons.brockport.edu/cgi/viewcontent.cgi?article=1011\&context=bus_facpub

5. Dahl W.A., Dobson W.D. An Analysis of Alternative Financing Strategies and Equity Retirement Plans for Farm Supply Cooperatives. American Journal of Agricultural Economics, 1976, vol. 58, iss. 2, pp. 198-208. URL: https://doi.org/10.2307/1238970

6. Gamba A., Triantis A. The Value of Financial Flexibility. The Journal of Finance, 2008, vol. 63, iss. 5, pp. 2263-2296. 
7. Jahangir A., Darron W., Gizelle W. The Value of Financial Advice: An Analysis of the Investment Performance of Advised and Non-advised Individual Investors. Investment Analysts Journal, 2016, vol. 45, iss. Sup1, pp. 63-74. URL: https://doi.org/10.1080/10293523.2016.1201292

8. Marchica M.T., Mura R. Financial Flexibility, Investment Ability and Firm Value: Evidence from Firms with Spare Debt Capacity. Financial Management, 2010, vol. 39, iss. 4, pp. 1339-1365.

URL: https://doi.org/10.2139/ssrn.891562

9. Samygin D.Yu., Baryshnikov N.G. Strategy of Support of Agrarian Business. Raleigh, North Carolina, USA, Lulu Press, 2017, 156 p.

10. Sillano M., Ortúzar J. Willingness-to-Pay Estimation with Mixed Logit Models: Some New Evidence. Environment and Planning A, 2005, no. 37, pp. 525-550. URL: https://doi.org/10.1068/a36137

11. Wang Y.-C. The Optimal Capital Structure in Agricultural Cooperatives under the Revolving Fund Cycles. Agricultural Economics (Czech), 2016, vol. 62, iss. 1, pp. 45-50.

URL: https://www.agriculturejournals.cz/publicFiles/173179.pdf

12. Filimonova N.G., Ozerova M.G., Ermakova I.N. Distinctions of the Crowdfunding Model in Agriculture. Digest Finance, 2018, vol. 23, iss. 1, pp. 98-107. URL: https://doi.org/10.24891/el.23.1.98

13. Mollick E. The Dynamics of Crowdfunding: An Exploratory Study. Journal of Business Venturing, 2014, vol. 29, iss. 1, pp. 1-16. URL: https://doi.org/10.1016/j.jbusvent.2013.06.005

14. Perova V.I., Korchemnyi P.V. [Neural simulation of behavior pattern of Russian agriculture development]. Ekonomicheskii analiz: teoriya i praktika = Economic Analysis: Theory and Practice, 2018, vol. 17, iss. 2, pp. 379-396. (In Russ.) URL: https://doi.org/10.24891/ea.17.2.379

15. Myakshin V.N. A Study into Structural Effects of Mutual Investment Induction in Sectoral Economic Systems. Digest Finance, 2017, vol. 22, iss. 3, pp. 274-285. URL: https://doi.org/10.24891/df.22.3.274

16. Ji S., Lim S.S. An Empirical Analysis of the Determinants of Agricultural Official Development Assistance. Agricultural Economics (Czech), 2018, vol. 64, iss. 5, pp. 206-215. URL: https://doi.org/10.17221/275/2016-AGRICECON

17. Ankarhem M., Daunfeldt S., Quoreshi S. et al. Do Regional Investment Grants Improve Firm Performance? Evidence from Sweden. Technology and Investment, 2010, vol. 1, iss. 3, pp. 221-227. URL: https://doi.org/10.4236/ti.2010.13027

18. Bergström F. Capital Subsidies and the Performance of Firms. Small Business Economics, 2000, vol. 14, iss. 3, pp. 183-193. URL: https://doi.org/10.1023/A:1008133217594

19. Harris R., Trainor M. Capital Subsidies and Their Impact on Total Factor Productivity: Firm-Level Evidence from Northern Ireland. Journal of Regional Science, 2005, vol. 45, iss. 1, pp. 49-74.

URL: https://doi.org/10.1111/j.0022-4146.2005.00364.x

20. Mezera J., Špička J. Economic Effects of Investment Support of Adding Value to Food Products. Agris On-line Papers in Economics and Informatics, 2013, no. 5, pp. 39-49.

URL: http://online.agris.cz/files/2013/agris_on-line_2013_1_mezera_spicka.pdf

\section{Conflict-of-interest notification}

We, the authors of this article, bindingly and explicitly declare of the partial and total lack of actual or potential conflict of interest with any other third party whatsoever, which may arise as a result of the publication of this article. This statement relates to the study, data collection and interpretation, writing and preparation of the article, and the decision to submit the manuscript for publication. 